Retno Issroviatiningrum, Dyah Wiji Puspita Sari, Ranti Kusumaningtiyas, Hubungan Efikasi Diri Dengan Hasil Evaluasi Osce Pada Mahasiswa D3 Keperawatan Di Fakultas IImu Keperawatan Universitas Islam Sultan Agung Semarang

\title{
HUBUNGAN EFIKASI DIRI DENGAN HASIL EVALUASI OSCE PADA MAHASISWA D3 KEPERAWATAN DI FAKULTAS ILMU KEPERAWATAN UNIVERSITAS ISLAM SULTAN AGUNG SEMARANG
}

\author{
${ }^{1}$ Retno Issroviatiningrum, \\ Fakultas IImu Keperawatan \\ Universitas Islam Sultan Agung Semarang, ners.ningrum@gmail.com \\ 2 Dyah Wiji Puspita Sari, dan ${ }^{3}$ Ranti Kusumaningtiyas \\ Fakultas IImu Keperawatan \\ Universitas Islam Sultan Agung Semarang
}

\begin{abstract}
ABSTRAK
Latar Belakang: Efikasi diri ialah keyakinan diri seorang individu akan kemampuan yang dipunyainya serta merupakan kesempatan untuk berhasil menyelesaikan tugas tertentu. OSCE diyakini memiliki kekuatan dalam upaya menumbuhkan keyakinan diri pada setiap individu mahasiswa, kemampuan klinis, wawasan dalam teori, serta motivasi sebagai perawat ahli Tujuan penelitian ini untuk mengetahui adakah hubungan antara efikasi diri dengan hasil evaluasi OSCE pada mahasiswa.
\end{abstract}

Metode: Penelitian ini adalah penelitian dengan menggunakan metode deskriptif korelasi. Teknik pengambilan sampel menggunakan total sampling dengan jumlah responden sebanyak 102 responden.

Hasil: Hasil penelitian diperoleh dari 102 responden, sebagian besar memiliki karakteristik jenis kelamin perempuan dengan persentase $88,5 \%$, responden dengan umur 19 tahun $94,1 \%$, responden dengan efikasi diri sedang $75,5 \%$, responden dengan hasil evaluasi OSCE kompeten $71,6 \%$.

Kesimpulan dan Saran: Penelitian ini didapatkan bahwa hubungan efikasi diri dengan hasil evaluasi OSCE pada mahasiswa D3 Keperawatan di Fakultas IImu Keperawatan Universitas Islam Sultan Agung Semarang terbanyak yaitu dengan kategori sedang.

Kata Kunci : Efikasi Diri, Hasil Evaluasi OSCE

\begin{abstract}
Background: Self-efficacy is an individual's self-confidence in the abilities he has and is an opportunity to successfully complete a particular task. OSCE is believed to have strengths in efforts to foster self-confidence in each individual student, clinical abilities, insights in theory, and motivation as expert nurses. The purpose of this study was to determine whether there is a relationship between self-efficacy and OSCE evaluation results on students.

Method: This research is a research using experimental research methods. The sampling technique uses total sampling with 102 respondents.

Results: The results of the study were obtained from 102 respondents, most of them had the characteristics of female sex with a percentage of $88.5 \%$, respondents with age 19 years $94.1 \%$, respondents with moderate self-efficacy $75.5 \%$, respondents with competent OSCE evaluation results $71.6 \%$.

Conclusion: This research was obtained about the relationship of self-efficacy with OSCE evaluation results in D3 Nursing students at the Faculty of Nursing at Sultan Agung Islamic University in Semarang with the medium category.
\end{abstract}

Keywords : Self-Efficacy, OSCE Evaluation Results

Jurnal IImu Kesehatan MAKIA, Vol.10 No.2, Agustus 2020

E - ISSN: 2549-9327, P - ISSN : 2407-6309 
Retno Issroviatiningrum, Dyah Wiji Puspita Sari, Ranti Kusumaningtiyas, Hubungan Efikasi Diri Dengan Hasil Evaluasi Osce Pada Mahasiswa D3 Keperawatan Di Fakultas IImu Keperawatan Universitas Islam Sultan Agung Semarang

\section{PENDAHULUAN}

OSCE diyakini memiliki kekuatan dalam upaya menumbuhkan keyakinan diri pada setiap individu mahasiswa, kemampuan klinis, wawasan dalam teori, serta motivasi sebagai perawat ahli (Rush et al., 2014). OSCE diyakini memiliki kekuatan dalam upaya menumbuhkan keyakinan diri pada setiap individu mahasiswa, kemampuan klinis, awasan dalam teori, serta motivasi sebagai perawat ahli (Rush et al., 2014). Meskipun begitu, Oranye et al., (2012) mengungkapkan separuh dari peserta didik ada yang belum lulus saat menjalankan OSCE. Sehingga mahasiswa sering tidak yakin akan dirinya sendiri dalam menjalankan ujian OSCE (self eficacy). Kreitner dkk (1998) mengungkapkan efikasi diri ialah keyakinan diri seorang individu akan kemampuan yang dipunyainya serta merupakan kesempatan untuk berhasil menyelesaikan tugas tertentu.

Hasil penelitian dari Fitriati (2018) menunjukkan korelasi antara efikasi diri dengan hasil evaluasi nilai signifikansi ( $p$ value) 0,030 bisa disimpulkan diantaranya keduanya ada hubungan antara self efficacy dengan hasil evaluasi OSCE. Mahasiswa tingkat 4 dan 6 lebih banyak memiliki pengalaman dalam belajar serta pengalaman dalam menjalankan ujian OSCE dibandingkan dengan mahasiswa tingkat 2. Hal yang serupa tersebut bisa menumbuhkan efikasi diri yaitu pengalaman pribadi diri seseorang, pengalaman kesuksesan yang sudah didapatkan maupun pengalaman kegagalan diperoleh bisa menumbuhkan efikasi diri.

\section{METODE}

Penelitian ini adalah jenis penelitian deskriptif korelasi, diantaranya jenis penelitian untuk menjelaskan hubungan antar variabel bebas dengan terikat. Pada penelitian ini yang ingin diketahui ialah hubungan antara efikasi diri dengan hasil OSCE pada mahasiswa D3 keperawatan semester 2 di Fakultas IImu Keperawatan Universitas Islam Sultan Agung Semarang.

Populasi dalam penelitian ini ialah mahasiswa prodi D3 keperawatan semester 2 di Fakultas IImu Keperawatan Universitas Islam Sultan Agung Semarang sebanyak 102 orang. Sampel penelitian disini memakai metode total sampling dimana tehnik pengambilan sampel sama dengan populasi (Sugiyono, 2007). Jadi besar sampel yang dipakai pada penelitian ini sebanyak 102 responden.

Instrumen penelitian menggunakan koesioner demografi, kuesioner efikasi diri dan dokumentasi evaluasi skill lab keperawatan. Koesioner demografi berisi identitas mahasiswa yang meliputi: inisial nama, jenis kelamin, dan umur.

Koesioner efikasi diri terdiri 27 pernyataan skala yang digunakan adalah skala likert Penilaian yang digunakan pada kuesioner yaitu menggunakan kategori respon sebagai berikut : sangat setuju (SS), setuju (S), tidak setuju (TS), sangat tidak setuju (STS), lalu diberi tanda contreng $(\sqrt{ })$.

Dokumentasi evaluasi skill lab keperawatan dilihat dengan panduan nilai menggunakan kategori sebagai berikut : (A) 81-100, (AB) : 71-80, (B) 62-70, (BC) 5561, (C) 51-54, (CD) 41-50, (D) 31-40, (E) 030.

\section{HASIL PENELITIAN DAN PEMBAHASAN}

\section{Analisa Univariat \\ a. Karakteristik Responden}

\section{1) Jenis Kelamin}

Tabel 1. Distribusi frekuensi berdasarkan jenis kelamin mahasiswa di Fakultas IImu Keperawatan Universitas Islam Sultan Agung Semarang pada bulan Desember $2019(n=102)$

\begin{tabular}{lll}
\hline $\begin{array}{l}\text { Jenis } \\
\text { Kelamin }\end{array}$ & $\begin{array}{c}\text { Frekuensi } \\
\text { (f) }\end{array}$ & $\begin{array}{l}\text { Persentase } \\
\%\end{array}$ \\
\hline Laki-laki & 10 & 9,6 \\
Perempuan & 92 & 88,5 \\
\hline Total & $\mathbf{1 0 2}$ & $\mathbf{1 0 0 , 0}$ \\
\hline
\end{tabular}


Retno Issroviatiningrum, Dyah Wiji Puspita Sari, Ranti Kusumaningtiyas, Hubungan Efikasi Diri Dengan Hasil Evaluasi Osce Pada Mahasiswa D3 Keperawatan Di Fakultas IImu Keperawatan Universitas Islam Sultan Agung Semarang

Dari tabel 1 bisa diketahui bahwa responden terbanyak ialah berjenis kelamin perempuan yaitu sebanyak 92 responden dengan persentase sebanyak $88,5 \%$, sedangkan responden paling sedikit ialah berjenis kelamin laki-laki yaitu sebanyak 10 responden dengan persentase $9,6 \%$.

Hasil penelitian ini didukung hasil oleh peneliti sebelumnya yang berkaitan dengan jenis kelamin menurut Fitriati (2018) bahwa responden terbanyak berjenis kelamin perempuan yaitu 59 responden dari 83 responden dengan persentase sebesar $71,1 \%$. Hasil penelitian yang sejalan juga menurut Perwitasari (2013) bahwa mahasiswa perempuan memiliki efikasi diri yang lebih tinggi dari pada mahasiswa laki-laki. Hasil diketahui dari rata-rata nilai efikasi diri pada mahasiswa laki - laki sebesar 2,263 sedangkan rata rata nilai efikasi diri pada mahasiswa perempuan sebesar 2,975.

\section{2) Umur}

Tabel 2. Distribusi frekuensi berdasarkan umur mahasiswa di Fakultas IImu Keperawatan Universitas Islam Sultan Agung Semarang pada bulan Desember $2019(n=102)$

\begin{tabular}{lll}
\hline $\begin{array}{l}\text { Umur } \\
\text { (Tahun) }\end{array}$ & $\begin{array}{l}\text { Frekuensi } \\
\text { (f) }\end{array}$ & $\begin{array}{l}\text { Persentase } \\
\text { (\%) }\end{array}$ \\
\hline 18 & 1 & 1,0 \\
19 & 96 & 94,1 \\
20 & 5 & 4,9 \\
\hline Total & $\mathbf{1 0 2}$ & $\mathbf{1 0 0 , 0}$ \\
\hline
\end{tabular}

Dari tabel 2 bisa diketahui responden terbanyak yaitu responden dengan usia 19 tahun sebanyak 96 responden dengan persentase $94,1 \%$, sedangkan responden paling sedikit yaitu responden dengan usia 18 tahun sebanyak 1 responden dengan persentase $1,0 \%$.

Hasil penelitian dari Dewi \& Ansyah (2018) tahun menunjukkan bahwa rentang umur 21-23 tahun mempunyai self efficacy lebih tinggi dibandingkan usia dibawahnya. Menurut hasil penelitian Permana dkk
(2016) tinggi rendahnya efikasi diri tersebut bisa dipengaruhi oleh banyaknya pengalaman yang diperoleh, derajad kesusahan, serta matangnya umur individu pada kematangan emosi dan fisiologis.

\section{3) Efikasi Diri}

Tabel 3 Distribusi frekuensi karakteristik efikasi diri pada mahasiswa D3 Keperawatan di Fakultas IImu Keperawatan Universitas Islam Sultan Agung Semarang pada bulan Desember $2019(n=102)$

\begin{tabular}{lll}
\hline Kategor & i Frekuensi & Persentase \\
\hline Rendah & 5 & 4,9 \\
Sedang & 77 & 75,5 \\
Tinggi & 20 & 9,6 \\
\hline Total & $\mathbf{1 0 2}$ & $\mathbf{1 0 0 , 0}$ \\
\hline
\end{tabular}

Dari tabel 3 dapat disimpulkan mahasiswa yang mempunyai efikasi tertinggi adalah dengan kategori sedang diri dengan kategori sebanyak 77 responden atau dengan persentase sebesar $75,5 \%$, dan mahasiswa yang mempunyai efikasi adalah dengan kategori efikasi rendah sebanyak 5 responden atau dengan persentase $4,9 \%$,.

\section{4) Hasil evaluasi OSCE}

Tabel 4 Distribusi frekuensi pada responden dengan hasil evaluasi OSCE mahasiwa D3 Keperawatan di Fakultas IImu Keperawatan Universitas Islam Sultan Agung Semarang pada bulan Desember $2019(n=102)$

\begin{tabular}{lll}
\hline Kategori & Frekuensi & Persentase \\
\hline Kompeten & 73 & $71,6 \%$ \\
Tidak & 29 & $28,4 \%$ \\
kompeten & & \\
\hline Total & $\mathbf{1 0 2}$ & $\mathbf{1 0 0 , 0 \%}$ \\
\hline
\end{tabular}

Dari tabel 4 diatas diperoleh kesimpulan hasil evaluasi OSCE pada mahasiswa D3 Keperawatan di Fakultas IImu Keperawatan Universitas Islam Sultan Agung Semarang sebanyak 102 responden dengan jumlah hasil diantaranya yaitu : kategori dengan hasil kompeten sebanyak 73 responden atau dengan persentase 
Retno Issroviatiningrum, Dyah Wiji Puspita Sari, Ranti Kusumaningtiyas, Hubungan Efikasi Diri Dengan Hasil Evaluasi Osce Pada Mahasiswa D3 Keperawatan Di Fakultas IImu Keperawatan Universitas Islam Sultan Agung Semarang

sebesar $71,6 \%$ dan kategori dengan hasil tidak kompeten sebanyak 29 responden atau dengan persentase sebesar $28,4 \%$.

\section{Analisa Bivariat}

a. Uji Normalitas

Tabel 5 Hasil uji normalitas variabel efikasi diri dengan hasil evaluasi OSCA di Fakultas IImu Keperawatan Universitas Islam Sultan Agung Semarang pada bulan Desember $2018(n=102)$

\begin{tabular}{llll}
\hline Variabel & $\mathbf{n}$ & $\begin{array}{l}\text { Sign } \\
\text { tailed) }\end{array}$ & $\mathbf{( 2 -}$ \\
\hline Jenis kelamin & 102 & 0,000 & \\
Umur & 102 & 0,000 \\
Efikasi diri & 102 & 0,002 \\
Hasil evaluasi & 102 & 0,000 \\
OSCE & & & \\
\hline
\end{tabular}

Dari tabel 5. bisa diketahui bahwa jenis kelamin, umur, dan kedua variable penelitian mempunyai nilai $p$-value atau sign (2-tailed) sebesar 0,000 dan 0,002 < 0,05 pada uji normalitas yang menggunakan Kolmogorov-Smirnov Test, sehingga dapat disimpulkan bahwa dalam penelitian jenis kelamin, umur, dan kedua variabel tidak berdistribusi normal. Selanjutnya dilakukan uji statistik non parametik menggunakan uji spearmen.

\section{b. Uji Spearmen}

Tabel 6 Hasil uji spearmen hubungan efikasi diri dengan hasil evaluasi OSCE pada mahasiswa D3 Keperawatan di Fakultas IImu Keperawatan Universitas Islam Sultan Agung Semarang pada bulan Desember $2019(n=102)$

\begin{tabular}{llll}
\hline Variabel & $\mathbf{n}$ & $\begin{array}{l}\text { Sign } \\
\mathbf{( 2 -} \\
\text { tailed) }\end{array}$ & $\begin{array}{l}\text { Correlation } \\
\text { coefficient }\end{array}$ \\
\hline Efikasi diri & 102 & 0,000 & 0,585 \\
Hasil evaluasi & 102 & 0,000 & 0,585 \\
OSCA & & & \\
\hline
\end{tabular}

Dari tabel 6 bisa diketahui bahwa nilai sign.(2-tailed) atau $p$-value pada uji spearmen yaitu dengan hasil $0,000<0,05$, sehingga bisa disimpulkan pada penelitian ini ada hubungan antara efikasi diri dengan hasil evaluasi OSCE pada mahasiswa D3 Keperawatan di Fakultas IImu Keperawatan Universitas Islam Sultan Agung Semarang. Selain itu diperoleh hasil nilai correlation coefficien yaitu 0,585 . Hasil ini berada pada rentang antara 0,51 - 0,71 menunjukkan bahwa keeratan hubungan antara dua variabel termasuk kategori kuat. Karena correlation menghasilkan nilai positif, maka hubungan yang diperoleh juga positif, artinya semakin tinggi nilai efikasi diri mahasiswa maka semakin tinggi tinggi juga hasil evaluasi OSCE mahasiswa atau sebaliknya.

Penelitian lainnya menurut Fitriati (2018) hasil korelasi antara efikasi diri dengan hasil evaluasi OSCE signifikansi ( $p$ value) 0,030 yaitu adanya hubungan yang signifikan antara efikasi diri dengan hasil evaluasi OSCE. Hasil yang sejalan sesuai kajian yang diteliti oleh Bandura (1997) bahwa ada hubungan positif antara efikasi diri dengan hasil belajar. Penelitian lain yang sejalan menurut Handayani \& Nurwidayati (2013), bahwa efikasi diri berpengaruh positif dan signifikan terhadap hasil akademik. Efikasi diri berhubungan dengan kepercayaan diri individu dalam mencapai keinginan yang diinginkan ataupun mengatasi tantangan dalam situasi apapun. Semakin tinggi kepercayaan diri yang dipunyai siswa maka dapat mendorong siswa untuk dapat melakukan tujuan sesuai dengan keinginan.

\section{c. Hubungan Efikasi Diri dengan Hasil Evaluasi OSCE pada Mahasiswa}

Tabel 5 Tabel silang hubungan efikasi diri dengan hasil evaluasi OSCE pada Mahasiswa D3 Keperawatan di Fakultas Ilmu Keperawatan Universitas Islam Sultan Agung Semarang pada bulan Desember $2019(n=102)$

\begin{tabular}{llll}
\hline Variabel & $\begin{array}{l}\text { Hasil } \\
\text { OSCE }\end{array}$ & Evaluasi & Total \\
\hline
\end{tabular}


Retno Issroviatiningrum, Dyah Wiji Puspita Sari, Ranti Kusumaningtiyas, Hubungan Efikasi Diri Dengan Hasil Evaluasi Osce Pada Mahasiswa D3 Keperawatan Di Fakultas IImu Keperawatan Universitas Islam Sultan Agung Semarang

\begin{tabular}{|c|c|c|c|c|c|c|c|}
\hline & & & & $\begin{array}{l}\text { Tic } \\
\text { ko } \\
\text { ter }\end{array}$ & $\begin{array}{l}\text { ak } \\
\text { npe }\end{array}$ & & \\
\hline & & $\mathrm{N}$ & $\%$ & $\overline{\mathrm{N}}$ & $\%$ & $\mathrm{~N}$ & $\%$ \\
\hline & $\begin{array}{l}\text { Ren } \\
\text { dah }\end{array}$ & 0 & $\begin{array}{l}0, \\
0\end{array}$ & 5 & $\begin{array}{l}10 \\
0 \\
\%\end{array}$ & 5 & $\begin{array}{l}10 \text { DA } \\
0,8 \text {, }\end{array}$ \\
\hline Efikasi Diri & $\begin{array}{l}\text { Sed } \\
\text { ang } \\
\text { Ting } \\
\text { gi }\end{array}$ & $\begin{array}{l}54 \\
19\end{array}$ & $\begin{array}{l}70 \\
, 1 \\
95 \\
, 0\end{array}$ & $\begin{array}{l}2 \\
3 \\
1\end{array}$ & $\begin{array}{l}29, \\
9 \\
5,0\end{array}$ & $\begin{array}{l}7 \\
7 \\
2 \\
0\end{array}$ & $\begin{array}{l}10 \\
0 \\
10 \\
0 \\
0\end{array}$ \\
\hline Total & & 73 & $\begin{array}{c}71 \\
6\end{array}$ & $\begin{array}{l}2 \\
9\end{array}$ & $\begin{array}{l}28 \\
4\end{array}$ & $\begin{array}{l}1 \\
0 \\
2\end{array}$ & $\begin{array}{l}10 \\
0,0\end{array}$ \\
\hline
\end{tabular}

0,05 dan keeratan hubungan yaitu kuat dengan nilai coefficient correlation sebesar positif 0,585.

Dari tabel 7 bisa diketahui dalam penelitian yang dilakukan peneliti bahwa mahasiswa dengan hasil efikasi diri yang rendah sebanyak 0 responden $(0,0 \%)$, mahasiswa dengan hasil efikasi diri sedang 54 responden $(70,1 \%)$, dan mahasiswa dengan hasil efikasi yang tinggi sebanyak 19 responden (95,0\%). Kemudian mahasiswa dari hasil evaluasi OSCE dengan hasil kompeten sebanyak 19 $(95,0 \%)$ sedangkan mahsiswa dari hasil evaluasi OSCE dengan hasil tidak kompeten sebanyak 1 responden $(5,0 \%)$.

\section{KESIMPULAN}

1. Kategori efikasi diri responden di Fakultas IImu Keperawatan Universitas Islam Sultan Agung Semarang terbanyak yaitu kategori sedang sebanyak 77 responden dengan persentase $75,5 \%$

2. Kategori hasil evaluasi OSCE responden Fakultas IImu Keperawatan Universitas Islam Sultan Agung Semarang terbanyak yaitu kategori cukup baik sebanyak 73 responden dengan persentase $71,6 \%$.

3. Terdapat hubungan yang dignifikan antara efikasi diri dengan hasil evaluasi OSCE di Fakultas IImu Keperawatan Universitas Islam Sultan Agung Semarang, dengan nilai sign.(2tailed) atau p-value sebesar 0,000 <
Handayani, F., \& Nurwidayati, D. (2013). Hubungan Self Efficacy Dengan Prestasi Belajar Siswa Akselerasi. Character, Volume 01, Nomer 02, Tahun 2013.

Kreitner R, Kinicki; A. (1998). Organizational behavior New york: McGraw Hill. 1998.

Oranye, N.O. (2012). Assessing nursing clinical skills competence through objective structured clinical examination (OSCE) for Open Distance Learning Students in Open University Malaysia. Contemporary Nurse, 41, 233-241.

Permana H, Harahap F, Astuti B. (2016). Hubungan antara efikasi diri dengan kecemasan dalam menghadapi ujian pada siswa kelas IX di mts al hikmah brebes. Jurnal Hisbah. 13(1):51-68.

Perwitasari, E.I. (2013). Perbedaan Efikasi Diri Mahasiswa Yang Sedang Menyusun Skripsi Ditinjau Dari Jenis Kelamin. Skripsi Fakultas Psikologi Universitas sanata Dharma Yogyakarta

Rush, S., Ann Ooms., Di MarksMaran., \& Terry Firth. (2014). Students perceptions of practice assessment 
Retno Issroviatiningrum, Dyah Wiji Puspita Sari, Ranti Kusumaningtiyas, Hubungan Efikasi Diri Dengan Hasil Evaluasi Osce Pada Mahasiswa D3 Keperawatan Di Fakultas IImu Keperawatan Universitas Islam Sultan Agung Semarang

in the skills laboratory: An evaluation study of OSCAs with immediate feedback. Nurse Education in Practice, 14, 627- 634.

Sugiyono. (2007). Metode Penelitian Kuantitatif Kualitatif dan $R \& D$. Bandung: Alfabeta. 